Jurnal Natur Indonesia 14(1), Oktober 2011: 107-113

ISSN 1410-9379, Keputusan Akreditasi No 65a/DIKTI/Kep./2008

\title{
Pemanfaatan Data Biologi Ikan Cakalang (Katsuwonus pelamis) dalam Rangka Pengelolaan Perikanan Bertanggung Jawab di Perairan Teluk Bone
}

\author{
Muhammad Jamal $^{{ }^{* *},}$, Muhammad Fedi Alfiadi Sondita ${ }^{2)}$, John Haluan²) dan Budy Wiryawan ${ }^{2)}$ \\ ${ }^{1)}$ Fakultas Perikanan dan Ilmu Kelautan, Universitas Muslim Indonesia, Makassar 90121 \\ ${ }^{2}$ Departemen PSP FPIK, Institut Pertanian Bogor, Bogor 16680 \\ Diterima 23-09-2010Ｄisetujui 11-05-2011
}

\begin{abstract}
The Bone Bay is part of Fisheries Management Zone WPPI 713 that covers Makassar strait, Flores sea and Bali sea. To such vast marine area, fisheries management can be started from smaller region, e.g. embayment waters. Biological characteristics of skipjack tuna (Katsuwonus pelamis) are some of important information for developing fisheries management in the area. This research was aimed to determine lengthweight relationship, size composititon, growth pattern and biologically feasible size of the fish. Data were obtained from fish caught by fisherman from Januari to December 2007. The bay was divided into three study areas, i.e. Northern, Centre and Southern Zones. The b coefficients for length-weight relationship in the three zones were equal 3 [not significant]. The average fork-length (FL) in each zone showed similar trends: increased from January to June, then stabilized until December. Using von Bertalanffy's growth model, the maximum FL $(\mathrm{L} \propto$ of $759.75 \mathrm{~mm}$ is estimated for fish at age of 84 months. The length at first maturity of the fish is $465 \mathrm{~mm}$ (FL).
\end{abstract}

Keywords: Bone bay, fisheries management, gonad maturity, Katsuwonus pelamis, size composition

\section{PENDAHULUAN}

Ekosistem Teluk Bone merupakan ekosistem yang mempunyai kekhasan tersendiri. Perairannya semi tertutup dibandingkan dengan perairan selat Makassar dan laut Flores karena secara geografis terletak di sebelah Timur daratan Sulawesi Selatan dan di sebelah Barat daratan Sulawesi Tenggara. Teluk Bone telah lama dimanfaatkan untuk usaha penangkapan ikan. Usaha penangkapan ikan yang ada masih dalam skala tradisional dan dalam jumlah yang cukup banyak. Salah satu sumberdaya perikanan yang dieksploitasi di Teluk Bone adalah ikan cakalang. Potensi ikan cakalang yang ada dipengaruhi oleh pola distribusi biofisik lingkungan secara spasial dan temporal. Lingkungan biofisik yang berada dekat mulut teluk (Laut Flores) dipastikan berbeda dengan lingkungan biofisik yang jauh dari mulut teluk.

Wilayah laut teluk Bone yang memiliki luas sekitar $31,837 \mathrm{~km}^{2}$ memiliki potensi sumberdaya perikanan yang cukup besar khususnya perikanan cakalang karena 59\% $(13,616)$ ton produksi ikan cakalang Sulawesi Selatan berasal dari Kawasan Teluk Bone (Dinas Perikanan dan Kelautan Sulawesi Selatan 2006). Meskipun sumberdaya perikanan tersebut dapat pulih (renewable resources) namun tingkat kecepatan pemulihannya dapat saja tidak seimbang dengan laju pemanfaatan. Oleh karena itu pemerintah bertanggungjawab menetapkan pengelolaan sumberdaya perikanan Indonesia untuk kepentingan seluruh masyarakat dengan memperhatikan kelestarian dan keberlanjutan sumberdaya tersebut.

Kegiatan usaha penangkapan ikan di Teluk Bone saat ini berlangsung secara bebas (open access) tanpa aturan dan pengendalian yang jelas sehingga semua nelayan dan alat tangkap yang ada di daerah pesisir kabupaten/kota bebas mengakses untuk menangkap ikan cakalang. Hingga saat ini, penangkapan ikan cakalang dilakukan tanpa pengaturan yang jelas sesuai dengan kaidah pengelolaan sumberdaya perikanan. Nelayan memiliki kecenderungan kapan dan dimana saja dengan bebas melakukan penangkapan termasuk ikan yang masih berukuran belum layak tangkap. Untuk keperluan pengelolaan sumberdaya ikan, maka informasi tentang komposisi ukuran, pola pertumbuhan dan ukuran ikan yang layak tangkap (legal size) akan menjadi sangat penting.

Tujuan penelitian ini adalah untuk menganalisis data biologis ikan cakalang yaitu komposisi ukuran, panjang berat, pertumbuhan dan length at first maturity $(\mathrm{lm})$ sebagai bahan dalam menyusun pengelolaan perikanan cakalang di kawasan Teluk Bone. Hasil penelitian dapat dijadikan sebagai bukti ilmiah (scintific evidents) dalam menyusun pengelolaan perikanan tangkap cakalang sehingga terwujud pengelolaan perikanan bertanggung jawab. 


\section{METODEPENELITIAN}

Penelitian ini telah dilaksanakan dari bulan Januari sampai Desember 2007 di Perairan Teluk Bone. Lokasi pengambilan data di kawasan Teluk Bone dibagi dalam tiga zona yaitu (1) zona Utara yaitu zona yang memiliki pengaruh yang kecil dari laut Flores sehingga zona ini relatif homogen, secara geografis zona utara berada pada $\leq 4^{0} \mathrm{LS}$ dengan fishing base di Suli Kabupaten Luwu ; (2) zona Tengah yaitu zona yang memiliki pengaruh yang sedang dari Laut Flores sehingga zona ini bersifat moderat, secara geografis zona tengah berada pada $4-5^{\circ} \mathrm{LS}$ dengan fishing base di Bajoe Kabupaten Bone dan (3) zona Selatan yaitu zona yang memiliki pengaruh yang besar dari Laut Flores sehingga zona ini sangat heterogen, secara geografis zona ini berada pada 5-6 ${ }^{0}$ LS dengan fishing base di Lappa Kabupaten Sinjai (Gambar 1).

Data biologi yang dikumpulkan adalah data panjang dan berat ikan. Data ini diperoleh dari hasil tangkapan nelayan pole and line pada setiap trip penangkapan yang didaratkan di Pangkalan Pendaratan Ikan (PPI) di lokasi penelitian. Rata-rata trip penangkapan di zona Utara adalah 14 trip/bulan, di zona Tengah adalah 12 trip/bulan dan di zona Selatan adalah 13 trip/bulan. Data panjang dan berat ikan diukur dari sampel ikan yang dipilih secara acak dari tempat penampungan ikan untuk menduga populasi (Potier \& Sadhotomo 1991; Supranto 2007). Jumlah sampel ikan yang diukur panjang dan beratnya adalah sebanyak 25 ekor per trip. Untuk mengetahui apakah sampel merupakan representasi dari populasi, maka dilakukan uji satu sampel untuk rata-rata dengan menggunakan uji t (Santoso \& Ashari 2005; Wibisono 2005). Pengukuran panjang ikan dilakukan dengan menggunakan measuring board dengan ketelitian 0,1 cm. Batas pengukuran panjang dimulai dari ujung mulut sampai ujung bagian dalam ekor (fork length). Berat ikan ditimbang dengan menggunakan timbangan pegas dengan kapasitas $21 \mathrm{~kg}$ dengan ketelitian $0,1 \mathrm{~kg}$.

Analisis Data. Hubungan Panjang Berat. Hubungan panjang (L) dan berat (W) ikan dilakukan secara terpisah antara ikan sampel di zona utara, zona Tengah dan zona Selatan. Perhitungan hubungan panjang dan berat serta indikator bentuk tubuh ikan cakalang (ramping, isometrik atau montok) mengacu pada rumus Effendie (1999), Fafioye \& Oluajo (2005), dan Kalayci et al. (2007). Untuk menguji nilai $\mathrm{b}=3$ dilakukan uji $\mathrm{t}(\mathrm{t}$-test) pada $\alpha=5 \%$, apakah hubungan panjang dan berat allometrik positif, allometrik negatif atau isometrik (Sparre \& Venema 1999).

Struktur Ukuran. Struktur ukuran ikan sampel pada setiap zona di kawasan Teluk Bone terlebih dahulu dianalisis

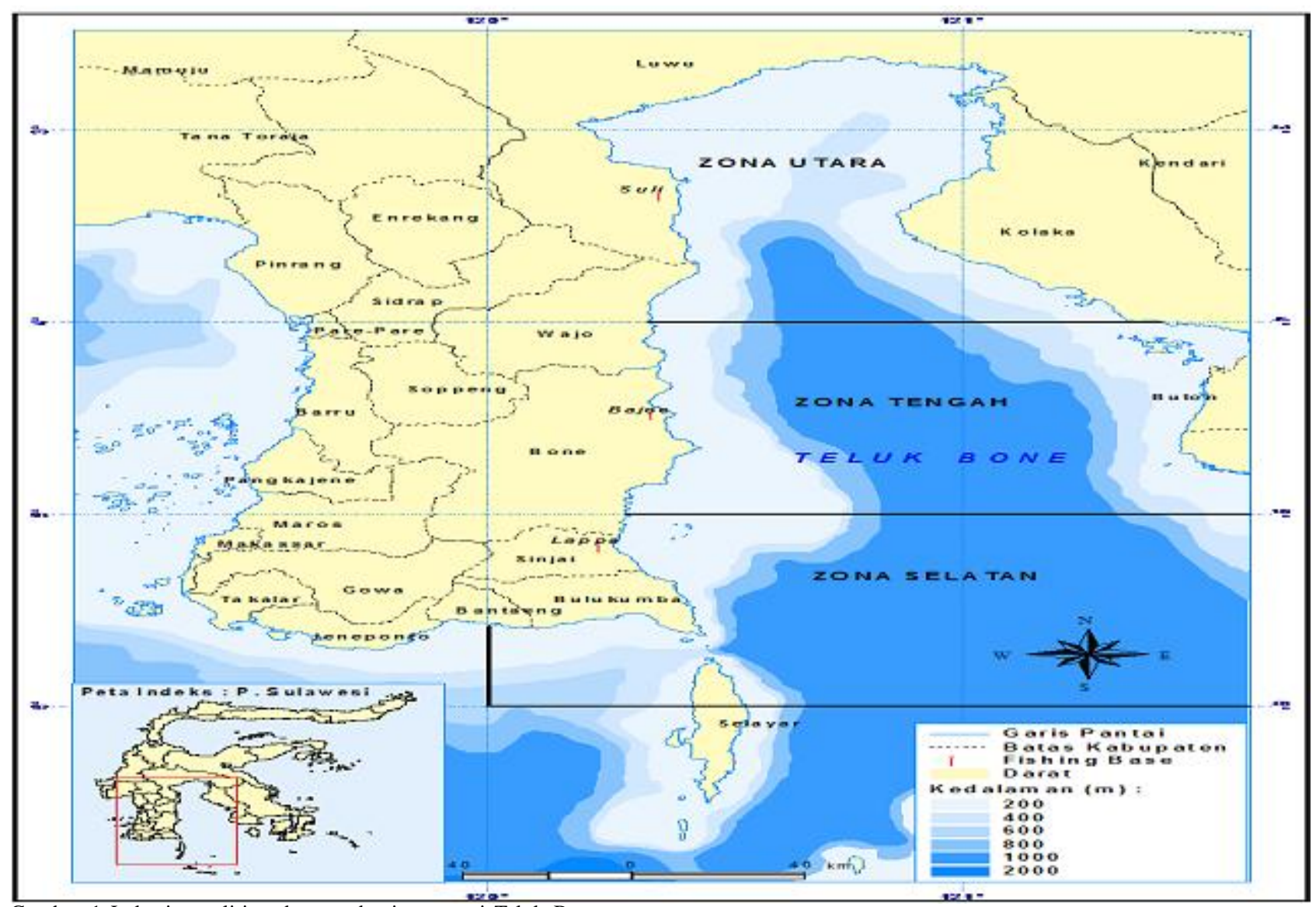

Gambar 1 Lokasi penelitian dan pembagian zonasi Teluk Bone 
dengan uji t satu sampel untuk menguji apakah sampel adalah representasi dari populasi, kemudian dibuat kelas panjang untuk menentukan frekuensi ukuran. Selanjutnya dibuat grafik dengan menggunakan program Microsoft Excel 2003.

Analisis Parameter Pertumbuhan. Untuk menduga pertumbuhan ikan cakalang terlebih dahulu ditentukan frekuensi panjang ikan. Selanjutnya ditentukan kelompok umur ikan dengan metode Tanaka (1960 diacu dalam Sparre \& Venema 1999). Hasil pengelompokan Cohort terhadap data frekuensi panjang diperoleh panjang rata-rata dari tiap kelompok umur. Nilai panjang rata-rata tersebut kemudian diplot terhadap umur sehingga diperoleh bentuk kurva pertumbuhannya. Pendugaan nilai koefisien pertumbuhan (K) dan panjang infinity $(\mathrm{L} \infty)$ diperoleh berdasarkan pada metode Forl-Walford (Sparre \& Venema 1999).

Setelah mengetahui nilai-nilai $\mathrm{K}, \mathrm{L}^{\infty}$ dan $\mathrm{t}_{0}$ dapat ditentukan model pertumbuhan dan hubungan umur-panjang ikan cakalang dari kawasan Teluk Bone dengan memasukkan nilai-nilai parameter pertumbuhan tersebut ke dalam model pertumbuhan Von Bertalanffy (1934 diacu dalam Sparre \& Venema 1999).

Ukuran layak tangkap. Ukuran ikan layak tangkap adalah ukuran ikan pada panjang pertama kali matang gonad (length at first maturity $=\mathrm{Lm}$ ). Untuk memperoleh nilai $\mathrm{Lm}$ dilakukan dengan cara membuat kurva sigmoid antara nilai tengah kelas dengan frekuensi kumulatif (\%) ikan cakalang contoh. Perpotongan antara $\mathrm{F}_{50}$ dengan kurva sigmoid adalah nilai $\mathrm{Lm}$.

\section{HASIL DAN PEMBAHASAN}

Hubungan panjang dan berat ikan. Jumlah sampel, panjang dan berat maksimum dan minimum, hubungan panjang dan berat, koefisien determinasi $\left(\mathrm{R}^{2}\right)$, tipe pertumbuhan (isometrik) dan rumus hubungan panjang berat ikan cakalang pada masing-masing zona disajikan pada Tabel 1. Koefisien b menunjukkan keseimbangan pertumbuhan panjang dan berat ikan; nilai koefisien $b$ memiliki trend meningkat mulai dari 2,506 di Zona Utara, 2,600 di Zona Tengah dan 2,773 di Zona Selatan.

Hasil uji $t_{\text {hitung }}$ terhadap koefisien $b$ di setiap zona tersebut adalah sama dengan 3 . Hal ini menunjukkan bahwa tubuh cakalang di kawasan Teluk Bone memiliki pola isometrik atau pertambahan panjang sama dengan pertambahan berat. Hasil yang sama diperoleh pula pada ikan cakalang yang tertangkap disebelah Barat Sulawesi Tengah dengan pola pertumbuhan isometrik (Telusa 1985). Namun berbeda dengan hasil penelitian yang dilakukan oleh Manik (2007), pada ikan cakalang yang tertangkap di sekitar pulau Seram dan Nusa Laut dan hasil penelitian pada sampel ikan cakalang yang dikumpulkan dari TPI Bungus Padang yang dilakukan oleh Merta (1989), yang memperoleh nilai b > 3 atau allometrik positif, artinya bahwa pertambahan panjang tidak secepat perrtambahan berat. Berbedanya hasil analisis tersebut mungkin karena diferensiasi kisaran panjang ikan yang dianalisis cukup besar, selain karena pengaruh faktor-faktor biologis dan ekologis dari masingmasing perairan di mana ikan itu hidup. Sedangkan menurut Sumadhiharga (1991), menyatakan perbedaan nilai b dipengaruhi oleh perbedaan musim dan tingkat kematangan gonad serta aktivitas penangkapan, karena aktivitas penangkapan yang cukup tinggi pada suatu daerah cukup mempengaruhi kehidupan dan pertumbuhan populasi ikan. Merta (1992) diacu dalam Manik (2007), menyatakan karena kondisi lingkungan sering berubah dan atau kondisi ikannya berubah, maka hubungan panjang berat akan sedikit menyimpang dari hukum kubik $(b \neq 3)$. Sedangkan menurut (Ricker 1973 diacu dalam Kalayci et al. 2007), menyatakan bahwa perbedaan tersebut dapat juga diakibatkan oleh faktor ekologi seperti temperatur, ketersediaan makanan, kondisi pemijahan atau faktor-faktor lain seperti kelamin, umur, daerah dan waktu penangkapan serta kapal penangkapan yang digunakan. Selanjutnya Matsumoto et al. (1984), melaporkan bahwa nilai b ikan cakalang berbeda-beda pada setiap lokasi penangkapan. Nilai terbesar $\mathrm{b}=3,67$ diperoleh dari lokasi Bonin island, West Pacific dan terkecil $b=1,70$ diperoleh dari Filipina.

Komposisi usuran. Hasil pengukuran rataan panjang ikan cakalang, kisaran dan standar deviasi selama penelitian berdasarkan zona dan periode bulan pengamatan disajikan pada Gambar 2. Perubahan rataan panjang cagak (FL) ikan cakalang di setiap zona menunjukkan trend yang sama dimana peningkatan dimulai dari Januari hingga Juni dan

Tabel 1 Statistik dan estimasi parameter hubungan panjang berat ikan cakalang di kawasan Teluk Bone

\begin{tabular}{|c|c|c|c|c|c|c|c|c|}
\hline & & Panjang cagak (mm) & Berat $(g)$ & $\mathrm{W}=$ & $\mathrm{aL}^{\mathrm{b}}$ & & & \\
\hline Zona & $\mathrm{N}$ & Min - Max & Min - Max & $\mathrm{a}$ & $\mathrm{b}$ & $\mathrm{R}^{2}$ & $\begin{array}{c}\text { Pertumbuhan } \\
(\mathrm{t}-\text { test })\end{array}$ & $\mathrm{P}$ \\
\hline Utara & 4200 & $292-610$ & $900-6100$ & 0,0006 & 2,5055 & 0,93 & $\mathrm{~b}=3$ & $\mathrm{~ns}$ \\
\hline Tengah & 3700 & $298-600$ & $1000-6000$ & 0,0003 & 2,5999 & 0,85 & $b=3$ & $\mathrm{~ns}$ \\
\hline Selatan & 3775 & $290-640$ & $800-6400$ & 0,0004 & 2,7733 & 0,92 & $\mathrm{~b}=3$ & $\mathrm{~ns}$ \\
\hline
\end{tabular}

Keterangan : ns = tidak signifikan 
stabil pada bulan-bulan berikutnya. Dalam periode JanuariApril, rataan FL cakalang di zona Utara umumnya lebih kecil dibandingkan dengan FL di zona Tengah dan Selatan, namun mulai Mei hingga Desember hampir sama (Gambar 2A). Range ukuran panjang ikan (FL) di zona Utara lebih besar dibandingkan di zona Tengah dan Selatan. Ukuran panjang ikan yang relatif seragam diperoleh di zona Tengah dan Selatan.

Perbedaan ukuran ini memberikan indikasi terjadinya migrasi atau perpindahan cakalang yang umumnya berukuran lebih besar ke zona Utara. Migrasi ikan cakalang ini berhubungan dengan ketersedian makanan di zona Utara yang lebih banyak dibanding zona Tengah. Hal ini terlihat dari konsentrasi klorofil-a di zona Utara yang mencapai $0,5 \mathrm{mg} / \mathrm{m}^{3}$ dan di zona Tengah konsentrasi klorofil-a hanya mencapai $0,2-0,3 \mathrm{mg} / \mathrm{m}^{3}$. Klorofil-a merupakan faktor yang
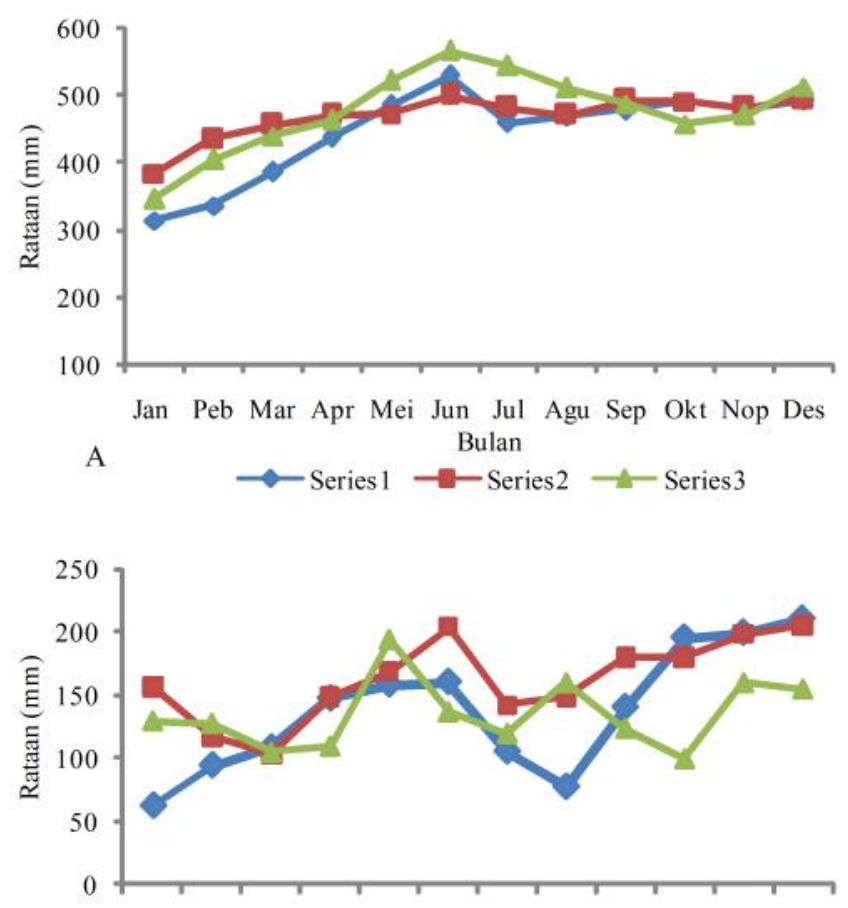

Jan Peb Mar Apr Mei Jun Jul Agu Sep Okt Nop Des B Bulan
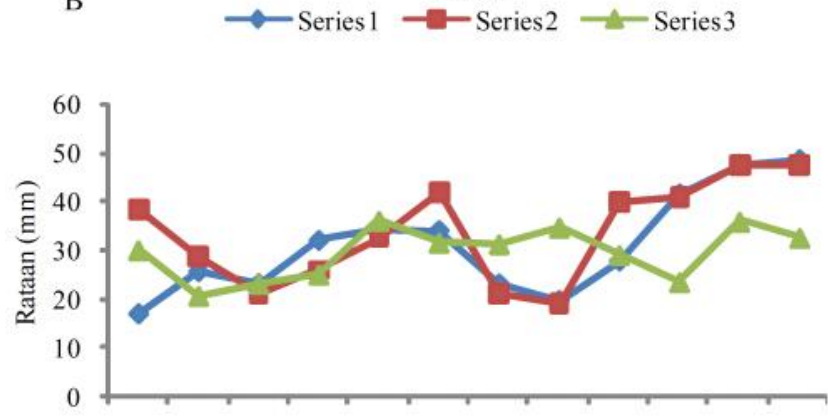

Jan Peb Mar Apr Mei Jun Jul Agu Sep Okt Nop Des $\mathrm{C}$ Bulan

$\longrightarrow$ Series $1 \longrightarrow$ Series $2-$ Series 3

Gambar 2 Hasil pengukuran panjang ikan cakalang (K. pelamis) pada setiap zona di perairan Teluk Bone A : Rataan ; B : kisaran ; C : stándar deviasi dapat memberikan indikasi langsung keberadaan makanan ikan maupun jalur wilayah migrasi ikan tuna (Polovina et al. 2001). Kandungan klorofil-a dapat juga digunakan sebagai ukuran banyaknya fitoplaknton pada suatu perairan tertentu dan dapat digunakan sebagai petunjuk produktivitas perairan. Daerah-daerah dengan nilai klorofil-a tinggi mempunyai hubungan erat dengan adanya proses penaikan massa air/upwelling (Nontji 1993).

Rataan ukuran FL setiap bulan pada masing-masing zona adalah sebagai berikut : zona Utara terkecil pada bulan Januari yaitu $315 \pm 16,6 \mathrm{~mm}$ dan terbesar bulan Juni yaitu $529 \pm 33,8 \mathrm{~mm}$; zona Tengah terkecil pada bulan Januari yaitu $384 \pm 38,3 \mathrm{~mm}$ dan terbesar pada bulan Juni yaitu 499 $\pm 41,9$ $\mathrm{mm}$ dan zona Selatan terkecil pada bulan Januari yaitu $347 \pm 30,1 \mathrm{~mm}$ dan terbesar pada bulan Juni yaitu $566 \pm 31,6 \mathrm{~mm}$. Kelompok ukuran ikan dengan frekuensi terbesar di zona Utara adalah kelas 450-459 mm (8,8\%), pada zona Tengah adalah kelas 450-459 mm (11,30\%) dan pada zona Selatan adalah kelas 500-509 $\mathrm{mm}(8,1 \%)$.

Hasil analisis frekuensi panjang ikan cakalang dengan metoda Tanaka (1960 diacu dalam Sparred \& Venema 1999), pada kawasan teluk Bone terdiri dari 4 (empat) kelompok umur dengan modus ukuran atau panjang rata-rata untuk ikan cakalang adalah 384 mm, 455 mm, 493 mm dan 549 mm. Penelitian lain yang dilakukan oleh Suhendrata et al. (1986 diacu dalam Hukom et al 1991), memperoleh 3 kelompok umur ikan cakalang yang tertangkap dengan alat pole and line di perairan sorong dengan menggunakan analisis modus yaitu $370 \mathrm{~mm}, 540 \mathrm{~mm}$ dan $640 \mathrm{~mm}$, selanjutnya diperoleh 4 kelompok umur ikan cakalang yang tertangkap di laut Banda yaitu 410 mm, 580 mm, 670 mm dan 720 mm, sedangkan kelompok umur ikan cakalang yang tertangkap di Pelabuhan Ratu dengan metode analisis modus diperoleh 4 kelompok umur yaitu $330 \mathrm{~mm}, 500 \mathrm{~mm}, 570 \mathrm{~mm}$ dan $660 \mathrm{~mm}$. Selanjutnya Sumadhiharga dan Hukom (1987), menyatakan bahwa sebaran frekuensi panjang cagak dari 5040 ekor ikan cakalang yang diukur menunjukkan panjang minimum 300 mm dan panjang maksimum $699 \mathrm{~mm}$, dengan kelompok ikan yang dominan terletak pada selang kelas 450-559 mm. Uktolseja (1987), menemukan frekuensi panjang cagak ikan cakalang di perairan sebelah timur Sulawesi Tengah tersebar di antara 271-577 mm. Sedangkan Suwartana (1986), yang meneliti di perairan Maluku Tengah mendapatkan panjang baku berkisar antara 403-654 mm. Komposisi ukuran ikan cakalang yang tertangkap dengan pole and line di perairan Kupang bervariasi mulai dari ukuran $290 \mathrm{~mm}$ sampai $589 \mathrm{~mm}$. Jumlah tangkapan terbanyak adalah ukuran 
470-499 mm (17,90\%) dan disusul oleh ukuran 440-469 mm (16,64\%), dan 380-409 mm (16,36\%) (Syamsuddin et al. 2008).

Parameter pertumbuhan. Hasil analisis frekuensi panjang menggunakan metode Tanaka (1960 diacu dalam Sparred \& Venema 1999), menghasilkan 4 kelompok umur, yaitu kelompok umur pertama lebih muda dari kelompok umur berikutnya sejalan dengan semakin panjangnya ukuran ikan. Analisis pertumbuhan berdasarkan metode Tanaka yang dilanjutkan dengan analisis metode plot Ford Walford menghasilkan persamaan pertumbuhan von Bertalanffy sebagai berikut: $\mathrm{Lt}=759,75\left\{1-\mathrm{e}^{0,19(\mathrm{t}+0,36)}\right\}$ dengan bentuk kurva seperti pada Gambar 3.

Persamaan tersebut memberikan indikasi bahwa cakalang mencapai FL maksimum $(\mathrm{L} \infty)$ sebesar 759,75 mm pada umur 84 bulan. Panjang maksimum ikan cakalang di
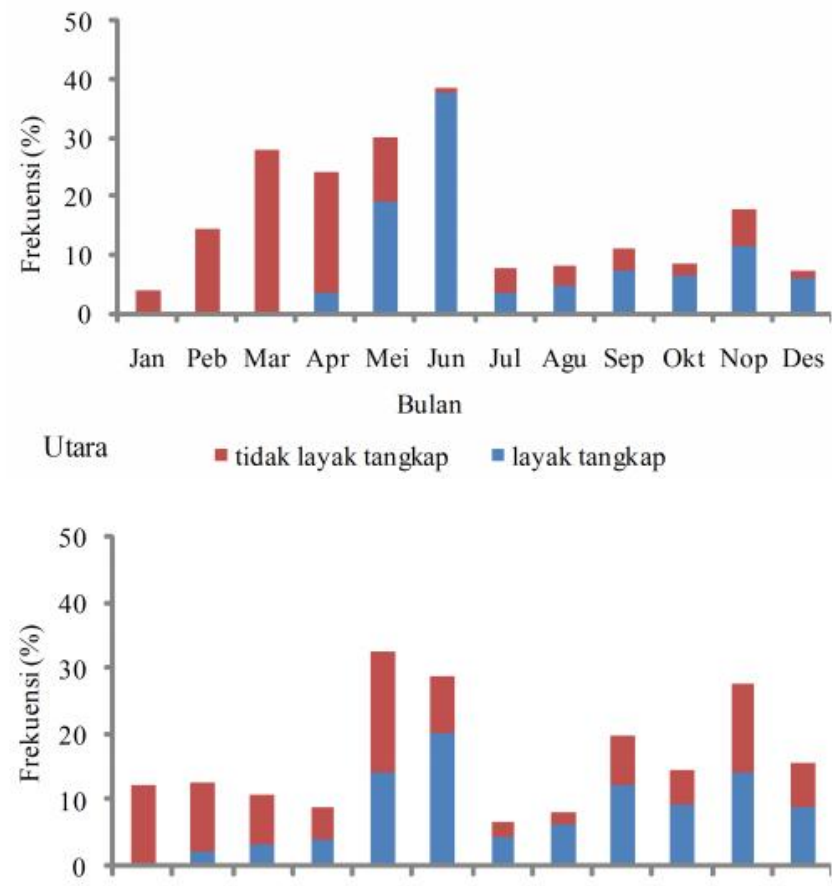

Jan Peb Mar Apr Mei Jun Jul Agu Sep Okt Nop Des
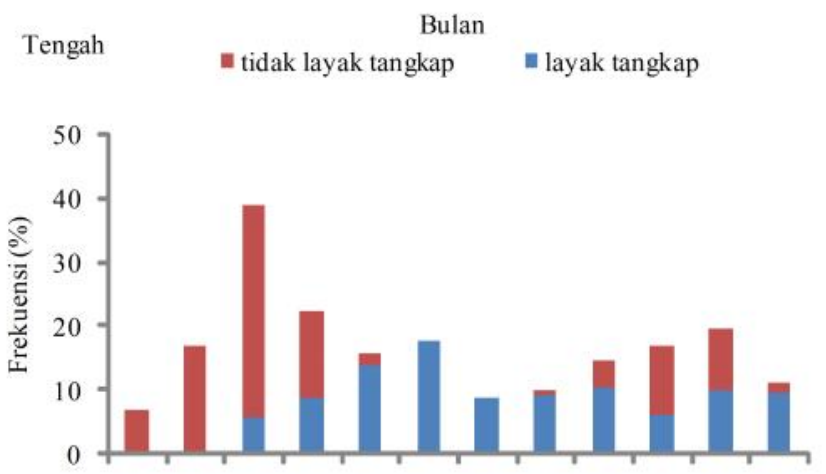

Jan Peb Mar Apr Mei Jun Jul Agu Sep Okt Nop Des Selatan Bulan

= tidak layak tangkap layak tangkap

Gambar 3 Pertumbuhan panjang ikan cakalang di perairan Teluk Bone kawasan Teluk Bone berbeda dari cakalang yang ditangkap di perairan Sumatera Barat, yaitu $\mathrm{L} \infty=87,8 \mathrm{~cm}$ pada umur 120 bulan (Merta 1989). Perbedaan nilai parameter pertumbuhan tersebut ( $\mathrm{L} \infty$ dan $\mathrm{K}$ ) dari spesies ikan yang sama pada lokasi yang berbeda dipengaruhi oleh faktor lingkungan masing-masing perairan seperti ketersediaan makanan, suhu perairan, oksigen terlarut, ukuran ikan dan kematangan gonad Merta 1992). Selanjutnya Widodo (1988), menyatakan bahwa kecenderungan ketidaktepatan nilai parameter pertumbuhan ikan dipengaruhi oleh komposisi ikan sampel yang dianalisis mengenai cara atau metode yang digunakan.

Matsumoto et al. 1984, mengulas metode dan berbagai studi pertumbuhan cakalang menyimpulkan bahwa menghitung tanda pertumbuhan periodik yang terdapat pada tulang punggung, sisik dan duri dorsal merupakan metode yang memberikan hasil yang akurat, disusul metode pergeseran modus. Penghitungan lingkaran harian (daily ring incrament) pada otolith memberikan hasil yang lebih baik dari kedua cara di atas, sedangkan menghitung pertumbuhan dengan cara tagging dan penangkapan ulang merupakan yang terakurat. Dikemukakan selanjutnya, bahwa pergeseran modus peka terhadap jumlah sampel yang sedikit. Hal ini menyebabkan pendugaan parameter pertumbuhan akan sangat bervariasi jika data yang digunakan sedikit.

Matsumoto et al. 1984, memperoleh laju pertumbuhan ikan cakalang sebesar $1,15 \mathrm{~cm}$ per bulan, yang diperoleh dengan menduga panjang ikan pada saat tertangkap kembali dan perubahan linier perubahan otolith untuk ikan yang ditandai (tagged) dan disuntik dengan tetracyclin.

Ukuran layak tangkap. Ikan layak tangkap didefenisikan sebagai ikan yang memiliki panjang yang lebih besar dari panjang pertama kali ikan matang gonad (length at frirst maturity, Lm). Nilai Lm cakalang di teluk Bone diperoleh sebesar $465 \mathrm{~mm}$. Nilai Lm ikan cakalang berbeda pada setiap tempat, namun umumnya lebih besar dari $40 \mathrm{~cm}$ (Tabel 2).

Keberlanjutan perikanan tangkap sebaiknya didukung oleh peraturan yang menetapkan ukuran ikan yang layak tangkap. Salah satu kriteria ikan layak ditangkap adalah memiliki panjang yang lebih besar dari panjang pertama kali ikan matang gonad (length at frirst maturity, Lm).

Berdasarkan nilai Lm dapat diketahui bahwa ukuran ikan layak tangkap di zona Utara dan Tengah >465-619 mm, sedangkan ukuran ikan layak tangkap di zona Selatan >465-649 mm. Kelompok cakalang yang layak tangkap di zona Utara umumnya terdapat pada April hingga Desember, 
Tabel 2 Beberapa nilai Lm ikan cakalang pada beberapa lokasi

\begin{tabular}{cccc}
\hline Nilai Lm $(\mathrm{cm})$ FL & Jenis kelamin ikan & Negara & Lokasi \\
\hline $\left.43,5-45,4^{*}\right)$ & - & USA & North Carolina \\
$\left.40,0-45,0^{*}\right)$ & betina & USA & Cuba \\
$\left.40,0^{*}\right)$ & betina & Polinesia & Marquesas and Tuamotu Islands \\
$\left.43,0^{*}\right)$ & - & Filipina & Bohol Sea \\
$43,0^{*}$ & - & Papua New Guinea & Papua New Guinea \\
$\left.45,0^{*}\right)$ & - & Madagaskar & Barat daya Madagaskar \\
$41-43^{* *}$ & - & &
\end{tabular}

*) Collette B.B and C. E. Naeun (1983) diacu dalam http://fishbase.org

**) Stequert (1976) diacu dalam Matsumoto et al. (1984)

Tabel 3 Jumlah contoh cakalang layak tangkap di setiap zona teluk Bone

\begin{tabular}{ccc}
\hline \multirow{2}{*}{ Zona } & \multicolumn{2}{c}{ Proporsi (\%) } \\
\cline { 2 - 3 } & Layak tangkap & Tidak layak tangkap \\
\hline Utara & 45,42 & 54,58 \\
Tengah & 56,11 & 43,89 \\
Selatan & 55,98 & 44,02 \\
\hline
\end{tabular}

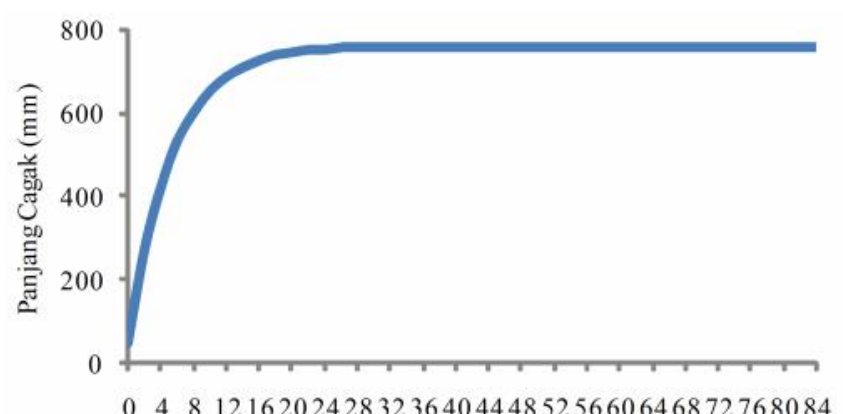

$\mathrm{L}$ infiniti $=759,75 \mathrm{~mm}$ Umur (bulan)

Gambar 4 Ukuran ikan layak tangkap setiap bulan pada masingmasing zona di perairan Teluk Bone

di zona Tengah pada Februari hingga Desember sedangkan di zona selatan pada Maret hingga Desember (Gambar 4).

Persentase tertinggi ikan layak tangkap berdasarkan zona didapatkan pada zona Tengah $56,11 \%$, zona Selatan $55,98 \%$ dan terendah pada zona Utara 45,42\% (Tabel 3). Hal ini menunjukkan bahwa ikan yang tertangkap dengan ukuran yang tidak layak 43,89-54,58\%. Tingginya ukuran ikan yang tidak layak menggambarkan bahwa nelayan belum mengetahui bulan-bulan penangkapan yang tidak berpengaruh terhadap keberlanjutan sumberdaya perikanan dan usaha penangkapan mereka. Ikan yang tertangkap sebelum matang gonad, diduga ikan tersebut belum sempat memijah sehingga hal ini akan mempengaruhi rekruitmen di daerah penangkapan tersebut.

Berdasarkan ukuran ikan layak tangkap tersebut, spesifikasi alat untuk menangkap cakalang dapat ditentukan untuk mendukung keberlanjutan perikanan tangkap. Misalnya, ukuran mata jaring untuk jaring insang dan pancing untuk huhate. Pengaturan spesifikasi alat tangkap ini merupakan jenis pengendalian input perikanan (King 1995).

\section{SIMPULAN}

Model pertumbuhan yang dihasilkan diperoleh nilai $b$ untuk ikan cakalang pada seluruh zona adalah $b=3$. Hal ini menunjukkan bahwa pertumbuhan ikan cakalang di kawasan teluk Bone berpola isometrik, yang mengandung arti pertumbuhan panjang tubuh ikan sama dengan pertumbuhan beratnya.

Panjang maksimum $(\mathrm{L} \infty)$ ikan cakalang di kawasan teluk Bone adalah 759,75 mm dalam waktu 84 bulan. Nilai Lm (Length at first of maturity) adalah $465 \mathrm{~mm}$ sehingga ikan yang berukuran layak tangkap adalah $465 \mathrm{~mm}$. Ikan yang tertangkap selama penelitian di atas $50 \%$ telah masuk ukuran layak tangkap kecuali di zona utara.

Waktu penangkapan ikan cakalang pada ketiga zona berdasarkan ukuran layak tangkap adalah Utara dari bulan April hingga Desember; Tengah bulan Februari hingga Desember dan Selatan bulan Maret hingga Desember.

Perlu dilakukan penelitian lanjutan tentang kondisi biofisik lingkungan perairan pada masing-masing zona dan pengaruhnya terhadap kondisi sumberdaya perikanan cakalang di Teluk Bone serta mengkaji model pengelolaan perikanan yang sesuai dengan kondisi kawasan perairan Teluk Bone.

\section{UCAPANTERIMAKASIH}

Ucapan terima kasih disampaikan kepada Direktorat Jenderal Pendidikan Tinggi Departemen pendidikan Nasional, Pemerintah Daerah Sulawesi Selatan, Rektor Universitas Muslim Indonesia dan Ketua Yayasan Insan Madani Mandiri Makassar yang telah membantu membiayai penelitian ini.

\section{DAFTAR PUSTAKA}

Dinas Kelautan \& Perikanan Sulsel. 2006. Laporan statistik perikanan. DKP Sulsel.

Effendie, M.I. 1997. Biologi perikanan: Yayasan Pustaka Nusatama

Fafioye, O.O. \& Oluajo, O.A. 2005. Length-weight relationship of five fish species in Epe Lagoon, Nigeria. African Journal of Biotechnology 4(7): 749-751.

Hukom, F.D., Wouthuyzen S. \& Manik, N. 1991. Studi tentang pertumbuhan ikan cakalang (Katsuwonus pelamis) yang tertangkap dengan pole and line di laut Banda. Jur.Fak,Perik,Unsrat 1(4): 58-67. 
Kalayci, F., Samsun, N., Bilgin, S. \& Samsun, O. 2007. Lengthweight relationship of 10 caught by bottom trawl and midwater trawl from the middle Black Sea, Turkey. Tourkish Journal of Fisheries and Aquatic Sciences 7: 33-36.

King, M. 1995. Fisheries biology, assessment and management. Fishing News Books. A Division of Blackwell Science Ltd. London.

Manik, N. 2007. Beberapa aspek biologi ikan cakalang (Katsuwonus pelamis) di perairan sekitar pulau Seram Selatan dan pulau Nusa Laut. Oseanologi dan Limnologi di Indonesia 33: 17-25.

Matsumoto, W.M., Skilman, R.A. \& Dizon, A.E. 1984. Synopsis of biological data on skipjack Tuna (Katsuwonus pelamis). NOAA Techical Report NMFS Circular No. 451 dan FAO Fihsries Synopsis No 136. Diterjemahkan oleh Fedi A. Sondita, 1999. Jurusan Pemanfaatan Sumberdaya Perikanan, IPB. Bogor.

Merta, I.G.S. 1989. Dinamika populasi ikan cakalang, Katsuwonus pelamis Linnaeus 1758 (Pisces : Scombridae) dari perairan Sumatera Barat. Jurnal Penelitian Perikanan Laut 53: 33-48.

Merta, I.G.S. 1989. Dinamika populasi ikan lemuru, Sardinella lamuru Bleeker 1953 (Pisces : Clupeidae) di perairan Selat Bali dan Alternatif Pengelolaannya. Disertasi Pasca Sarjana, Bogor: IPB.

Nontji, A. 1993. Laut Nusantara. Jakarta. Djambatan.

Pauly, D. 1983. Some simple methods for the assesment of tropica fish stocks. FAO Fisheries Technical Paper No. 234. 52p.

Polovina, J.J., Howel, E., Kobayashi, D.R. \& Seki, M.P. 2001 The transition zone chlorophyll front, a dynamic global feature defining migration and forage habitat for marine resources. Progress in Oceanogr. 49: 469-483.

Potier, M. \& Sadhatomo, B. 1991. Sampling training. Java sea pelagic fishery assesment project. Agency for Agricultura Research and Development, Research Institut for Marine Fisheries, Jakarta, 24p.

Santoso, P. B. \& Ashari. 2005. Analisis statistik dengan microsof excell dan SPSS. Yogyakarta: Penerbit Andi
Sparre, P. \& Venema, S.C. 1999. Introduksi pengkajian stok ikan tropis. Badan Penelitian dan Pengembangan Perikanan. Diterjemahkan oleh Pusat Penelitian dan Pengembangan Perikanan, Badan Penelitian dan Pengembangan Perikanan, Jakarta.

Species Katsuwonus pelamis Linnaeus. 1758. http://fishbase.org. (20 Desember 2007).

Sumadhiharga, K. \& Hukom, F.D. 1987. Hubungan panjang berat, makanan dan reproduksi ikan cakalang (Katsuwonus pelamis) di laut Banda. Makalah pada Kongres Biologi Nasional VIII. Purwokerto.

Sumadhiharga, K. 1991. Struktur populasi dan reproduksi ikan momar merah (Decapterus ruselli) di teluk Ambon. Di dalam : BPPSL. Pusat penelitian dan Pengembangan Oseanologi - LIPI. Perairan Muluku dan Sekitarnya.

Supranto, J. 2007. Teknik sampling untuk survey dan eksperimen.J akarta: Rineka Cipta.

Suwartana, A. 1986. Struktur populasi ikan cakalang (Katsuwonus pelamis) di Maluku Tengah. Jurnal Penelitian Perikanan Laut 34: $99-109$

Syamsuddin, Mallawa, A., Najamuddin \& Sudirman. 2008. Analisis Pengembangan Perikanan Ikan Cakalang (Katsuwonus pelamis Linneus)Berkelanjutan Di Kupang Propinsi Nusa Tenggara Timur. Disertasi Pasca Sarjana. Makassar: UNHAS.

Telusa, P,S. 1985. Komposisi, morfometrik dan beberapa sifat meristik jenis-jenis ikan tuna yang tertangkap di Maluku Tengah. Tesis Pasca Sarjana, Bogor: IPB.

Uktolseja, J.C.B. 1987. Estimated growth parameters and migration of skipjack tuna-Katsuwonus pelamis In: Balai Penelitian Perikanan Laut. The Eastern Indonesian Water Through Tagging Experiments. Jakarta.

Wibisono, Y. 2005. Metode statistik, Yogyakarta: Gajah Mada University Press

Widodo, J. 1988. Population dynamics and management of ikan layang, Decapterus spp (Carangidae) in the Java Sea. Jurnal Penelitian perikanan Laut 47: 11-44. 